\title{
Monsoon changes for 6000 years ago: Results of 18 simulations from the Paleoclimate Modeling Intercomparison Project (PMIP)
}

\author{
S. Joussaume, ${ }^{1}$ K. E. Taylor, ${ }^{2}$ P. Braconnot, ${ }^{1}$ J. F. B. Mitchell, ${ }^{3}$ J. E. Kutzbach, ${ }^{4}$ \\ S.P. Harrison, ${ }^{5,6}$ I. C. Prentice, ${ }^{6,7}$ A. J. Broccoli, ${ }^{8}$ A. Abe-Ouchi, ${ }^{9}$ P. J. Bartlein, 10 \\ C. Bonfils, ${ }^{1}$ B. Dong, ${ }^{11}$ J. Guiot, ${ }^{12}$ K. Herterich, ${ }^{13}$ C. D. Hewitt, ${ }^{3}$ D. Jolly, $5,6,7$ \\ J. W. Kim, ${ }^{14}$ A. Kislov, ${ }^{15}$ A. Kitoh, ${ }^{16}$ M. F. Loutre, ${ }^{17}$ V. Masson, ${ }^{1}$ B. McAvaney, ${ }^{18}$ \\ N. McFarlane, ${ }^{19}$ N. de Noblet, 1 W. R. Peltier, 20 J.Y. Peterschmitt, 1 D. Pollard, 21 \\ D. Rind, 22 J. F. Royer, ${ }^{23}$ M. E. Schlesinger, 24 J. Syktus, ${ }^{25}$ S. Thompson, 26 \\ P. Valdes, ${ }^{11}$ G. Vettoretti, ${ }^{20}$ R. S. Webb, ${ }^{27}$ U. Wyputta 13
}

\begin{abstract}
Amplification of the northern hemisphere seasonal cycle of insolation during the mid-Holocene causes a northward shift of the main regions of monsoon precipitation over Africa and India in all 18 simulations conducted for the Paleoclimate Modeling Intercomparison Project (PMIP). Differences among simulations are related to differences in model formulation. Despite qualitative agreement with paleoecological estimates of biome shifts, the magnitude of the monsoon increases over northern Africa are underestimated by all the models.
\end{abstract}

\section{Introduction}

The reliability of climate models in predicting climate change on the regional scales where ecological and economic

\footnotetext{
${ }^{1}$ Laboratoire des Sciences du Climat et de l'Environnement, Gif sur Yvette, France

2 PCMDI, Lawrence Livermore National Laboratory, USA

${ }^{3}$ Hadley Centre, Bracknell, UK.

${ }_{5}^{4}$ Center for Climatic Research, Unuv Wisconsin, USA.

5 Dynamic Palaeoclimatology, Lund University, Sweden

${ }_{7}^{6}$ Max Planck Institute for Biogeochemistry, Jena, Germany

${ }^{7}$ School of Ecology. Lund University, Sweden

${ }^{8}$ NOAA/Geophysical Fluid Dynamics Laboratory, Princeton University, USA.

${ }^{9}$ Center for Climate System Research, University. Tokyo, Japan

${ }^{10} \mathrm{Dpt}$. of Geography, University Oregon, USA

11 Dpt. of Meteorology, University reading, UK.

12 IMEP CNRS, Faculté de St-Jérôme, Marseille, France

13 University Bremen, Germany.

14 Yonsel University, Seoul, Korea.

15 Dpt Meteorology and Climatology, University Moscow, Russia.

${ }_{16}$ Meteorological Research Institute, Tsukuba, Japan.

17 Institut d'Astronomie et de Géophysique. UCL, Belgique

18 Bureau of Meteorology Research Centre, Melbourne, Australia.

19 Canadian Centre for Climate Modelling and Analysis, Victoria.

${ }^{20}$ Dpt Atmospheric Science, University of Toronto. Canada

${ }^{21}$ Earth System Science Center. Pennsylvania State University, USA

22 NASA Goddard Institute for Space Studies, USA.

${ }^{23}$ Centre National de Recherches Météorologiques, Toulouse, France

24 Dpt Atmospheric Sciences, University Illinois, USA.

${ }^{25}$ CSIRO Division of Atmospheric Research, and Queensland Centre for Climate Applications, Australia

${ }^{26}$ National Center for Atmospheric Research, Boulder, USA

${ }^{27}$ NOAA/Geophysical Data Center, Boulder, USA.
}

Copyright 1999 by the American Geophysical Union.

Paper number 1999GL900126.

0094-8276/99/1999GL900126\$05.00 impacts of global climate change occur needs to be assessed. Current models exhibit a range of skill in simulating today's climate [Gates et al., 1998] and can produce quite different regional responses to a given forcing [Kattenberg et al., 1995]. Even if models could simulate today's climate perfectly, this would not guarantee accurate simulation of climate change. Attempting to simulate substantially different past climatic conditions allows one to evaluate model responses to climate changes. The Paleoclimate Modeling Intercomparison Project (PMIP) [Joussaume and Taylor, 1995] has coordinated carefully designed simulations of past climates. The aim is to compare the climate response of different models, to determine, where possible, the reasons for differences in response, and to use paleodata to discriminate, where appropriate, between realistic and unrealistic responses. The PMIP project was strongly influenced by the pioneering work of the Cooperative Holocene Mapping Project [COHMAP-Members, 1988].

The mid-Holocene period ( 6000 years ago, $6 \mathrm{ka} \mathrm{BP}$ ) was chosen as one focus for PMIP because there is compelling evidence that regional climates were significantly different from today [Wright et al., 1993], extensive quality-controlled data syntheses are available [e.g., $Y u$ and Harrison, 1996; Prentice and Webb $I I I$, in press] and the external forcing can be precisely defined (Tab. 1). Each of the 18 PMIP models (Tab. 2) simulated equilibrium climates under present-day forcing and with $6 \mathrm{ka}$ BP orbital parameters [Berger, 1978] and atmospheric $\mathrm{CO}_{2}$ concentration [Raynaud et al.. 1993]. Sea surface temperatures (SSTs), vegetation and land-surface characteristics were prescribed as for present day in both simulations. Note that fixing the SSTs limits the impact of $\mathrm{CO}_{2}$ changes. The estimated differences in SST between $6 \mathrm{ka} \mathrm{BP}$ and today are generally small [e.g., Ruddiman and Mix, 1993]. This simple design aids intercomparison but can not be expected to yield complete agreement with paleodata. The results for each model were averaged over at least a 10-year period, following a one-year

Table 1. Forcing Conditions for the $6 \mathrm{ka}$ BP Simulations.

\begin{tabular}{lcc}
\hline & Present-day & $6 \mathrm{ka} \mathrm{BP}$ \\
\hline orbital parameters & & \\
Eccentricity & 0.016724 & 0.018682 \\
Axial tilt ( $\left.{ }^{\circ}\right)$ & 23.446 & 24.105 \\
perihelion- $180^{\circ}\left({ }^{\circ}\right)$ & 102.04 & 0.87 \\
$\mathrm{CO}_{2}$ concentration & 345 ppm or $\mathrm{C}_{\mathrm{ctrl}}$ & 280 ppm or \\
& & $\mathrm{C}_{\mathrm{ctrl}} *(280 / 345)$ \\
\hline
\end{tabular}


Table 2. Model Designation, Horizontal (Spectral Modes or Longitude $x$ Latitude Number of Grid Points) and Vertical (L) Resolutions. Ancillary Information Indicates Whether the Model Versions have been used for Future Climate Simulations (C), or in : (A) Atmospheric Model Intercomparison Project, (F) Feedback Analysis and Intercomparison for GCMs and Observations for Cloud and Snow Feedbacks, (P) Project for Intercomparison of Land-surface Parametrization Schemes. Model Descriptions are Available at the PMIP web Site (http://www-pcmdi.llnl.gov/pmip).

\begin{tabular}{|c|c|c|c|c|}
\hline & Model designation & Version & Resolution & CAFP \\
\hline $\begin{array}{l}\text { 1- BMRC } \\
\text { 2- CCC2 } \\
\text { 3- CCM3 } \\
\text { 4-CCSR1 } \\
\text { 5- CNRM2 } \\
\text { 6- CSIRO } \\
\text { 7- ECHAM3 } \\
\text { 8- GEN2 } \\
\text { 9- GFDL } \\
\text { 10- GISS } \\
\text { 11- LMD4 } \\
\text { 12- LMD5 } \\
\text { 13- MRI2 } \\
\text { 14- MSU } \\
\text { 15- UGAMP } \\
\text { 16- UIUC11 } \\
\text { 17- UKMO } \\
\text { 18- YONU }\end{array}$ & $\begin{array}{l}\text { Bureau of Meteorology Research Centre (Australia) } \\
\text { Canadian Centre for Climate Modelling and Analysis (Canada) } \\
\text { NCAR Climate Community Model (USA) run at CCR } \\
\text { Center for Climate System Research (Japan) } \\
\text { Centre National de Recherches Météorologiques (France) } \\
\text { Common wealth Scientific and Industrial Research Organisation (Australia) } \\
\text { Max-Planck Institut fuer Meteorologie (Germany) run at Bremen Univ. } \\
\text { National Center for Atmospheric Research (USA) GENESIS model } \\
\text { Geophysical Flujd Dynamics Laboratory (USA) } \\
\text { Goddard Institute for Space Studies (USA) } \\
\text { Laboratoire de Metéorologie Dynamique (France) run at LSCE } \\
\text { Laboratoire de Méteorologie Dynamique (France) run at LSCE } \\
\text { Meteorological Research Institute (Japan) } \\
\text { Moscow State University (Russia) } \\
\text { UK Universities Global Atmospheric Modelling Programme } \\
\text { University of Ilinois Urbana-Champaign (USA) } \\
\text { UK Meteorological Office Unified Model } \\
\text { Yonsei University (Korea) }\end{array}$ & $\begin{array}{l}\text { V.3.3 } \\
\text { V.2 } \\
\text { V3 } \\
\text { V.5.4.02 } \\
\text { V.2 } \\
\text { V.4-7 } \\
\text { V.3.6 } \\
\text { V. } 2 \\
\text { V.II prime } \\
\text { V. } 4 \text { ter } \\
\text { V. } 5.3 \\
\text { V. II.b } \\
\text { V.2 } \\
\text { V. } 3.2 \\
\text { Tr7.1.1 }\end{array}$ & $\begin{array}{c}\text { R21, L9 } \\
\text { T32, L10 } \\
\text { T42, L18 } \\
\text { T21, L20 } \\
\text { T31, L19 } \\
\text { R21, L9 } \\
\text { T42, L19 } \\
\text { T31, L18 } \\
\text { R30, L20 } \\
72 * 46, \text { L9 } \\
48 * 36, \text { L11 } \\
64 * 50, \text { L11 } \\
72 * 46, \text { L15 } \\
10 \times 15, \text { L3 } \\
\text { T42, L19 } \\
72 * 46, \text { L11 } \\
96 * 73, \text { L19 } \\
72 * 46, \text { L8 }\end{array}$ & $\begin{array}{l}\text { YYYN } \\
\text { YYYN } \\
\text { YNNY } \\
\text { YYNN } \\
\text { YNNY } \\
\text { YYNN } \\
\text { YYYY } \\
\text { YYNN } \\
\text { YNNY } \\
\text { YYYY } \\
\text { YNYY } \\
\text { YYYY } \\
\text { YYNN } \\
\text { YNNN } \\
\text { YYNN } \\
\text { YNNN } \\
\text { YNYY } \\
\text { NNNN }\end{array}$ \\
\hline
\end{tabular}

spin up. The seasons were defined using a modern calendar with vernal equinox fixed at 21 March [Joussaume and Braconnot, 1997].

\section{Model Results}

We focus on the response of the northern hemisphere monsoons, which are a consistent feature of the model simulations and paleodata. At $6 \mathrm{ka} \mathrm{BP}$, insolation increases (decreases) in the northern hemisphere summer (winter) by about $5 \%$ over the northern hemisphere. The seasonal cycle of temperature over land is enhanced in the northern hemisphere and reduced in the southern hemisphere. The summer warming reaches a maximum of $2-2.5{ }^{\circ} \mathrm{C}$ over eastern Asia (not shown). The resulting increased land-sea temperature contrast enhances low-level convergence into the monsoon low over northern Africa and Eurasia. This increases precipitation along the southern side of the monsoon flow over subtropical Africa and northern India

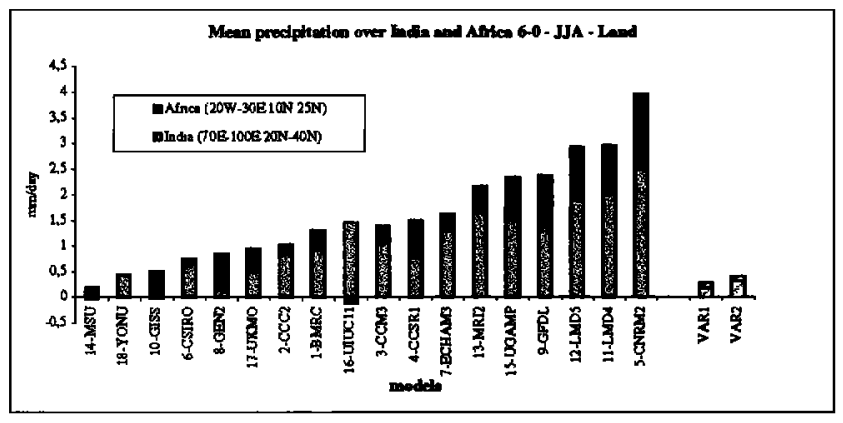

Figure 1. Simulated precipitation changes over northern India (70-100E, 20-40N; grey color) and northern Africa (20W$30 \mathrm{E}$ and $10-20 \mathrm{~N}$; black), compared to interdecadal variability estimated from standard deviations based on long coupled simulations of the GFDI. (VAR-1) [Manabe and Stouffer, 1996] and UKMO (VAR-2) [Tett et al., 1997] models.
(Figure 1). These changes are consistent with earlier simulations [e.g. Kutzbach and Otto-Bliesner, 1982] and qualitatively robust across all PMIP models. Figure 1 shows that almost all models produce an increase in precipitation over northern India (70-100E, 20-40N) and over northern Africa (20W-30E, 1025N). Precipitation increases vary from model to model, from 0 . to $2.5 \mathrm{~mm} /$ day over northern India and 0 . to $1.5 \mathrm{~mm} /$ day over northern Africa, changes that are generally larger than interdecadal variability simulated by coupled atmosphereocean models (Figure 1). The simulated increase of monsoon precipitation also differ spatially which explains why a few models exhibit no change in these limited-area averages.

The range of precipitation increases over northern India is correlated (correlation coefficient $r=0.75$, significant at the 95\% level) with the range of warming over Central Asia (40$150 \mathrm{E}, 30-60 \mathrm{~N})$. The latter varies across models from 0.6 to $2.1^{\circ} \mathrm{C}$, which is greater than the standard deviation of decadal variability estimated by coupled climate models $\left(0.16^{\circ} \mathrm{C}\right.$ for GFDL and $0.40^{\circ} \mathrm{C}$ for UKMO) (Figure 2a). This correlation is consistent with land/sea thermal contrast driving the monsoon [Prell and Kutzbach, 1987]. Although all the models are forced by the same changes in incoming radiation (ca $22 \mathrm{Wm}^{-2}$ over central Asia in JJA), model differences in present-day planetary albedo lead to differences in the shortwave forcing (defined here as the insolation-induced change in net shortwave flux at the top of the atmosphere when present day planetary albedo is assumed). This explains part of the temperature range (Figure 2b). Differences in cloud feedbacks [e.g. Cess et al., 1990] also modulate the net top of the atmosphere radiation changes and account for some of temperature differences (Figure $2 \mathrm{~b}$ ). For example, model 2 , with the smallest warming, has a negative cloud feedback arising from increased reflection of solar radiation, whereas model 12, with the second largest warming, has the largest positive cloud feedback. Differences in cloud feedbacks can arise for many reasons, including differences in landsurface parameterizations [Masson and Joussaume, 1997] or cloud schemes [e.g. Liao et al., 1994]. 

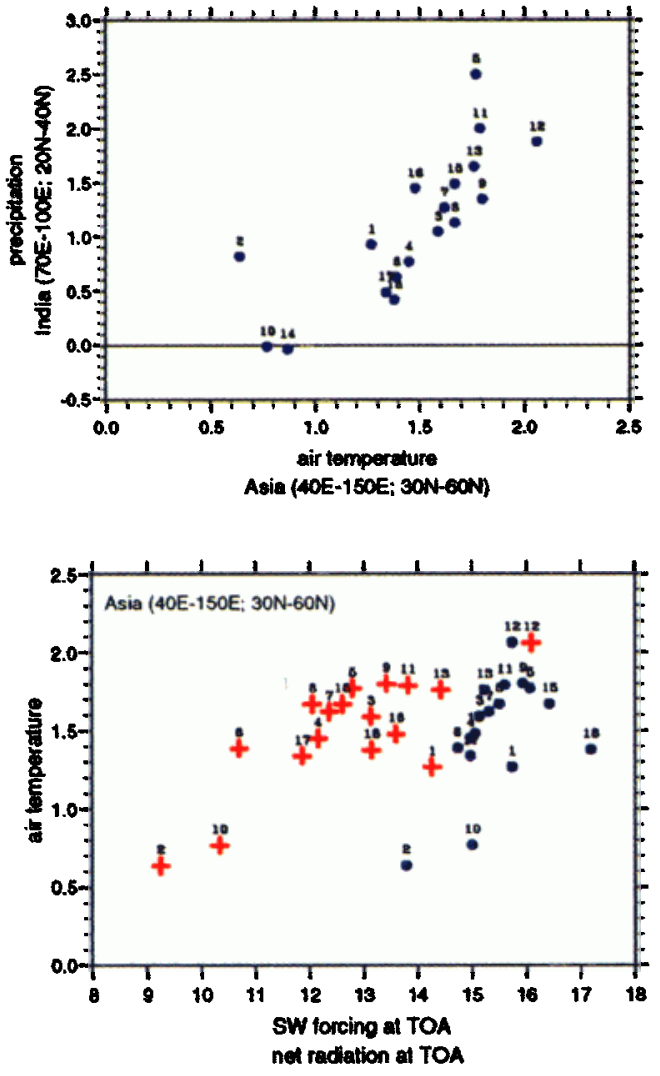

Figure 2. Monsoon changes in June-July-August. a) Relationship between precipitation changes over northern India (70-100E, 20-40N) (mm/day) and changes of surface air temperatures over central Asia $(40-150 \mathrm{E}, 30-60 \mathrm{~N})\left({ }^{\circ} \mathrm{C}\right)$ for all the simulations. b) Relationship over central Asia between changes in surface air temperature $\left({ }^{\circ} \mathrm{C}\right)$ and net short wave forcing (dots) ( $\left.\mathrm{Wm}^{-2}\right)$ and changes in the net top of the atmosphere radiation (crosses) $\left(\mathrm{Wm}^{-2}\right)$ for all the models except model 14 (for which these diagnostics were unavailable).

\section{Comparison with Paleoclimate Data from Africa}

Geomorphic and biostratigraphic evidence indicates that northern Africa was considerably wetter than today and extensively vegetated in the mid-Holocene and that lakes were present in now-dry basins as far north as $27 \mathrm{~N}$, and in the northwestern part of north Africa [Jolly et al., 1998a]. Pollen- and plant macrofossil-based reconstructions of $6 \mathrm{ka} \mathrm{BP}$ vegetation in northern Africa show that grasslands (steppe) were found at least as far north as $23 \mathrm{~N}$, and that no plants characteristic of desert were present south of $20 \mathrm{~N}$ at that time [Jolly et al., 1998b; Figure 3b].

In order to compare model results with paleovegetation data, we consider the annual mean changes in precipitation averaged over northern Africa from $20 \mathrm{~W}$ to $30 \mathrm{E}$. All the models produce increased precipitation in the northern part of their present-day rainbelt (Figures $3 \mathrm{a}$ and $3 \mathrm{c}$ ), in qualitative agreement with reconstructed vegetation shifts (Figure $3 \mathrm{~b}$ ). Maxima of precipitation changes vary from model to model (Figure 3a). The models in which the maximum change at $6 \mathrm{ka} \mathrm{BP}$ is furthest north (models 1, 8, 11, 13 and 18) are also those in which the northern limit of the rainbelt is furthest north in the control. Using the known moisture-balance requirements of grassland vegetation (Figure 3a), we estimate that at least an additional 100 $\mathrm{mm} /$ year would be required for most models to sustain grassland at $23 \mathrm{~N}$, i.e. more than twice as much as simulated in this area. Thus none of the model precipitation changes would sustain steppe as far north as reconstructed from the data [see e.g. Harrison et al., 1998]

\section{Discussion and Conclusion}

The qualitative consistency in the monsoon enhancement at $6 \mathrm{ka} \mathrm{BP}$ is remarkable given the wide range of resolution and the variety of subgrid-scale parameterizations in the models. It contrasts with the wide range of response shown in simulations with doubled $\mathrm{CO}_{2}$ [Kattenberg et al., 1995]. At 6 ka BP, the patterns of response are anchored by the land/sea distribution because the increase in land-sea temperature contrast drives the hydrologic response. This is true even in simulations with computed SSTs [e.g. Liao et al., 1994]. Nevertheless, there are large differences in model sensitivity. We have shown that differences in precipitation intensity can be related to differences in both the present day albedo and cloud feedbacks. To fully understand the origin of differences in these feedbacks on climate, specific sensitivity experiments performed with individual models will be required.

None of the PMIP models produces a large enough northward shift of the monsoon rainfall, consistent with the reconstructed changes in vegetation over northern Africa. We have

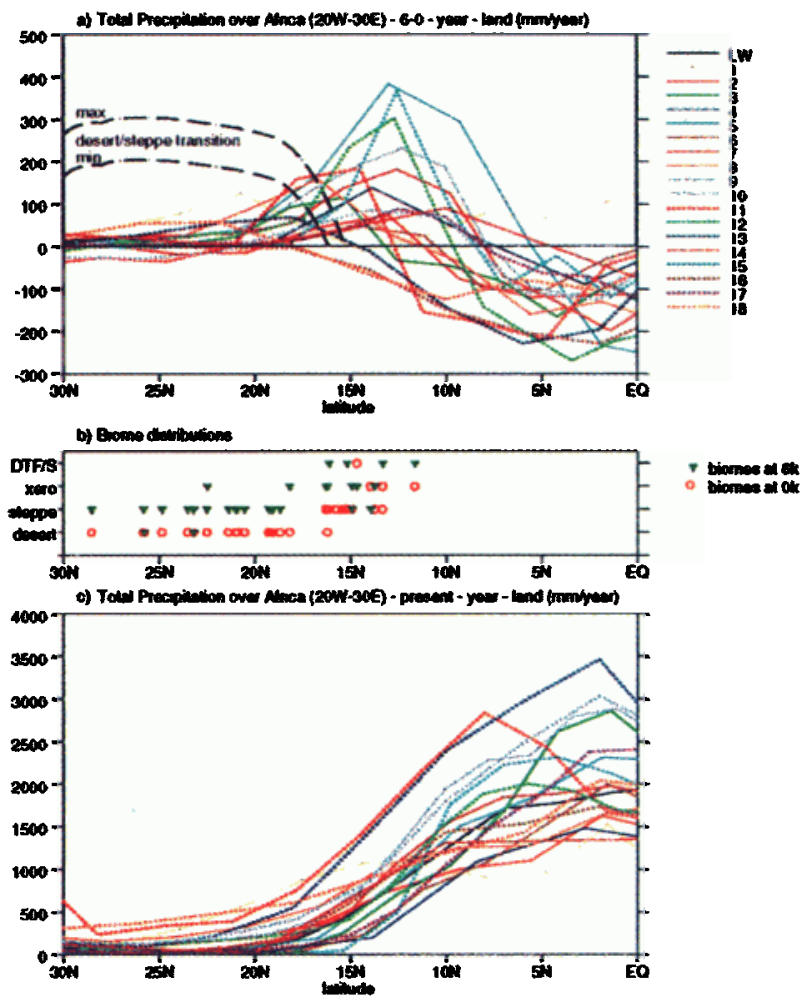

Figure 3. Zonal average climate and distribution of biomes in northern Africa (20W-30E). (a) $6 \mathrm{ka} \mathrm{BP}$ minus present annual precipitation ( $\mathrm{mm} /$ year). The hatched lines are estimated upper and lower bounds for the excess precipitation required to support grassland, based on present climatic limits of desert and grassland taxa in paleoecological records (D. Jolly and I.C. Prentice, unpublished results). b) Biome distributions (desert, steppe, xerophytic and dry tropical forest/savannah (DTF/S), 6 ka BP and present c) Simulated present day annual precipitation (mm/year) compared to climatology [Legates and Willmott (LW), 1990]. 
deliberately omitted the vegetation, lake and ocean temperature feedbacks on climate. Experiments in which mid-Holocene vegetation changes in the Sahara were (a) represented by decreases in surface albedo [Street Perrott et al., 1990], (b) prescribed from observations [Kutzbach et al., 1996], or (c) calculated interactively [Texier et al., 1997; Claussen and Gayler, 1997] produced larger increases and a greater northward extension of the rainfall over northern Africa. Including the observed occurrence of large lakes [Coe and Bonan, 1997] or coupling with a full ocean model [Kutzbach and Lik, 1997; Hewitt and Mitchell, 1998] has the same effect though no experiment produces the northward extent derived from paleodata. Future work will determine if this failure is model-dependent or results from the omission of synergistic interactions between the ocean, vegetation and surface-water storage. Such investigations are particularly important. given the state-of-the-art simulations of future climates also do not include vegetation and surface-water storage feedbacks.

Acknowledgements. Financial support for some of the PMIP simulations and for the analysis performed here was provided by EU under PMIP contracts EV5V-CT94-0457 and ENV4-CT95-0075, by the PNEDC, the Swedish Natural Science research Council, and by several individual grants from funding agencies in the U.S.A. and eslwhere. We thank PCMDI for archiving the PMIP data base and providing graphic software support, and we thank NGDC for their help in storing the PMIP boundary conditions. We used PMIP data base vesrsion 01/12/98. Interdecadal variability from long coupled runs were kindly provided by R. Stouffer (GFDL) and M. Eagles (UKMO). We also thank EU, NOAA, NSF and PAGES for supporting workshops that have fostered discussions leading to this paper.

\section{References}

Berger, A., Long-term variation of daily insolation and Quaternary climatic changes, J. Atmos. Sci., 35, 2362-2367, 1978.

Cess, R.D., and 31 co-authors, Intercomparison and interpretation of climate feedback processes in 19 atmospheric general circulation models, J. Geophys. Res., 95, 16601-16615, 1990.

Claussen. M., and V. Gayler. The greening of Sahara during the midHolocene: results of an interactive atmosphere-biome model, Global Ecol Biogeogr. Lett., 6, 369-377. 1997.

Coe, M.T., and G.B. Bonan, Feedbacks between climate and surface water in northern Africa during the middle Holocene, J. Geophys. Res., 102, 11,087-11,101, 1997.

COHMAP-Members, Climatic changes of the last 18,000 years: observations and model simulations, Science. 24l. 1043-1052, 1988.

Gates, W.L., and 15 co-authors, An overview of the results of the Atmospheric Model Intercomparison Project (AMIP I), Bull. Amer Meteor. Soc., in press, 1998.

Harrison, S.P., and 11 co-authors, Intercomparison of simulated global vegetation distributions in response to $6 \mathrm{kyr}$ BP orbital forcing, $J$. Clim., 11, 2721-2742., 1998.

Hewitt, C.D., and J.F.B. Mitchell, A fully coupled GCM simulation of the climate of the mid-Holocene, Geophys. Res. Lett. 25, 361-364. 1998.

Jolly, D., S.P. Harrison, B. Damnat, and R. Bonnefille, Simulated climate and biomes of Africa during the Late Quaternary: comparison with pollen and lake status data, Quat. Sci. Rev. 17, 629-657, 1998a.

Jolly, D.. and 32 co-authors, Biome reconstruction from pollen and plant macrofossil data for Africa and the Arabian peninsula at 0 and $6 \mathbf{k a}$, J. Biogeogr. 1998b.

Joussaume, S., and P. Braconnot, Sensitivity of paleoclimate simulation results to season definitions, J. Geophys. Res., 102, 1943-1956, 1997.

Joussaume, S., and K.E. Taylor, Status of the Paleoclimate Modeling Intercomparison Project (PMIP), in Proceedings of the first intermational AMIP scientific conference, WCRP Report, 425-430, 1995.
Kattenberg, A., F. Giorgi, H. Grassl, G.A. Meehl, J.F.B. Mitchell, R.J. Stouffer, T. Tokioka, A.J. Weaver, and T.M.L. Wigley, Climate Models- Projections of Future Climate, in Climate Change 1995, edited by T. Houghton et al., pp 285-357, Cambridge University Press, 1995.

Kutzbach, J.E., G. Bonan, J. Foley, and S. Harrison, Vegetation and soil feedbacks on the response of the African monsoon to forcing in the early to middle Holocene, Nature, 384, 623-626, 1996.

Kutzbach, J.E., and Z. Liu, Response of the African monsoon to orbital forcing and ocean feedbacks in the Middle Holocene, Science, 278, 440-443, 1997.

Kutzbach, J.E., and B.L. Otto-Bliesner, The sensitivity of the AfricanAsian monsoon climate to orbital parameter changes for 9000 years B.P. in a low-resolution general circulation model, J. Atmos. Sci., 39, 1177-1188, 1982.

Legates, D.R., and C.J. Willmott, Mean seasonal and spatial variability in gauge-corrected precipitation, Int. J. Climatol., 10, 111-127, 1990.

Liao, X., A. Street-Perrott, and J.F.B. Mitchell, Two GCM experiments for 6000 years BP, Comparisons with Palaeoclimatic reconstructions, Palaeoclimates - Data and Modelling, I, 99-123, 1994.

Manabe, S., and R.J. Stouffer, Low-frequency variability of surface air temperature in a 1000 -year integration of a coupled atmosphereocean-land surface model, J. Clim., 9, 376-393, 1996.

Masson, V., and S. Joussaume, Energetics of the 6000 BP atmospheric circulation in boreal summer, from large scale to monsoon areas: a study with two versions of the LMD AGCM. J. Clim., 10, 2888-2903. 1997.

Prell, W.L., and J.E. Kutzbach, Monsoon variability over the past 150,000 years, J. Geophys. Res., 92, 8411-8425, 1987.

Prentice, I.C., and T. Webb III, BIOME 6000: reconstructing global midHolocene vegetation patterns from palaeoecological records, $J$. Biogeogr., in press, 1998

Raynaud, D., J. Jouzel, J.-M. Barnola , J. Chappelaz, R. Delmas, and C. Lorius, The ice record of greenhouse gases, Science. 259, 926-934. 1993.

Ruddiman, W.F., and A.C. Mix. The north and equatorial Atlantic at 9000 and 6000 yr BP, in Global climates since the Last Glactal Maximum, edited by H.E.J. Wright et al., pp 94-124,Univ. Minnesota Press, Minneapolis, 1993.

Street Perrott, F.A., J.F.B. Mitchell, D.S. Marchand, and J.S. Brunner. Milankovitch and albedo forcing of the tropical monsoons: a comparison of geological evidence and numerical sımulations for $9000 \mathrm{yr} \mathrm{BP}$ Transactions of the Royal Society of Edinburgh, 81, 407, 1990.

Tett, S.F.B., T.C. Johns, and J.F.B. Mitchell, Global and regional variability in a coupled GCM, Climate Dyn., 13, 303-323, 1997.

Texier, D., N. de Noblet, S.P. Harrison, A. Haxeltine, D. Jolly, S. Joussaume, F. Laarif, I.C. Prentice. and P. Tarasov, Quantifying the role of biosphere-atmosphere feedbacks in climate change: coupled model simulations for 6000 years BP and comparison with paleodata for northern Eurasia and northern Africa, Climate Dyn., 13, 865-882, 1997.

Wright, H.E.J., J.E. Kutzbach, T. Webb III, W.F. Ruddiman, F.A. StreetPerrott, and P.J. Bartlein, In Global climates since the Last Glacial Maxımum, edited by H.E.J. Wright et al.. Univ. Minnesota Press. Minneapolis, 1993.

Yu, G., and S.P. Harrison, An evaluation of the simulated water balance of northern Eurasia at 6000 yr B.P. using lake status data, Climate Dyn. 12, 723-735, 1996.

S. Joussaume, Laboratoire des Sciences du Climat et de l'Environnement, UMR CEA-CNRS 1572, CEA Saclay bat 709, 91191 Gif sur Yvette cedex, France (email: joussaume@cea.fr)

K. Taylor, PCMDI, Lawrence Livermore National Laboratory, Ljvermore, CA 94550, USA (email: taylor13@llnl.gov)

Other author adresses are available ar the PMIP Web Site. (http://www-pcondi.llnl.gov/pmip)

(Received December 3, 1998; Revised January 28, 1999; accepted February 16. 1999) 